\title{
Increasing the efficacy of the cotton leaf worm Spodoptera littoralis nucleopolyhedrosis virus using certain essential oils
}

\author{
Waheed Ahmed Abdelhanid Sayed ${ }^{1 *}$ D, Helmy El-Bendary ${ }^{2}$ and Alexandra El-Helaly ${ }^{3}$
}

\begin{abstract}
Baculoviruses inactivation by UV sunlight is considered one of the most important factors that reduce their potential use in insect management programs. The three antioxidant essential oils, marjoram, orange, and tea tree were tested as protective additives to the multiple nucleopolyhedrosis virus (SpliMNPV) against UV. The results revealed that the orange oil was promising for virus protection, while the tea tree oil and marjoram oil did not protect the virus. The results also showed that the pathogenicity of the combination treatment of SpliMNPV and orange oil was increased drastically by adding the $\mathrm{LC}_{50}(1.0 \%)$ concentration of the oil to the virus concentrations. Consequently, the $\mathrm{LC}_{50}$ of the mixture was reduced to $5.3 \times 10^{3} \mathrm{PIB} / \mathrm{ml}$ compared to $3.2 \times 10^{5} \mathrm{PIB} / \mathrm{ml}$ concentration of virus alone. Concomitantly, the ovicidal and larvicidal effects of orange oils were determined. The results suggested that the combination treatment of orange oil and SpliMNPV could be used as an effective method for the cotton leaf worm, Spodoptera littoralis (Boisd.), management.
\end{abstract}

Keywords: SpliMNPV, Adjuvant agent, UV irradiation, Essential plant oils, Protective additives

\section{Background}

Baculoviruses are one of the most environmental safe bio-pesticides for lepidopteran pests. They are unique of the viruses groups that exclusively infect insect pests and often are highly specific at species levels causing epizootics in the populations of target insects. (Sayed and El-Helaly 2018). The cotton leaf worm Spodoptera littoralis (Boisd.) (Lepidoptera: Noctuidae) multiple nucleopolyhedrosis virus (SpliMNPV) is one of the Baculovirus groups that is specific for S. littoralis and can be used effectively in its management. However, it is severely affected by the UV radiation of sunlight, which leads to pyrimidine dimer formation in the viral DNA chains and consequently reduces the SpliMNPV persistence in the field (Jones et al. 1993 and Yoon et al. 2000). Despite many trials that have been attempted to protect the viral activity, the search for new effective technique in this

\footnotetext{
* Correspondence: waheed.sayed@eaea.org.eg

${ }^{1}$ Biological Application Department, Nuclear Research Center, Atomic Energy

Authority Cairo, Cairo, Egypt

Full list of author information is available at the end of the article
}

respect is continuously required. Shapiro et al. (2009b) tested 13 plant phenolics for protecting Spodoptera exigua (Hubner) nucleopolyhedrovirus (SeMNPV). Moreover, 20 naturally derived antioxidants were suggested for SpliMNPV protection (El-Helaly et al. 2013). Evidently, sub-lethal concentrations of insecticides could increase the efficacy of NPV pathogenicity and act as adjuvants for virus infectivity, for instance Neem (Shapiro et al. 1994), thiamethoxame and imidacloprid (Trang and Chaudhari 2002), and Spinosad (Jackson et al. 2014). In this context, it can be suggested that the use of an agent to protect the virus degradation by UV light that has insecticidal activity as well as being environmentally safe may make the bio-control strategy of $S$. littoralis more effective and promising. Recently, the essential plant oils have been shown a broad spectrum of actions to insect responses, as many of such oils have been defined as antioxidants with different degrees (Miguel et al., 2010); additionally, they may possess low to high anti-arthropods action against insect pests with a low risk to mammalian (Tripathi et al. 2009 and 
Regnault-Roger et al. 2012). The three essential plant oils, orange, tea tree, and marjoram, have been provided as antioxidant substrates (Bakkali et al. 2008). Interestingly, the toxic activities of orange oil was reported by Raina et al. (2007) on Subterranean termites. Moreover, the plant tea oil was recommended as larvicide of Sitophilus zeamais (Mot.) (Liao et al. 2016). Furthermore, the marjoram proved to be effective against Sitophilus oryzae (Linn.) and Tribolium castaneum (Herbst) (Padin et al. 2000).

The present trial aimed to evaluate the use of three commercial plant oils, orange, tea tree, and marjoram, as adjuvants to SpliNPV activity for lepidopteran pest control.

\section{Materials and methods}

\section{Insect, virus, and material}

The cotton leaf worm, Spodoptera littoralis (Boisduval), was established at the laboratory conditions of $25 \pm 2{ }^{\circ} \mathrm{C}$ and $65 \pm 5 \%$ R.H. Newly hatched larvae were reared on semi-artificial diet (Shorey and Hale 1965). Pupae were collected in plastic cups until adult emergence. Adults were transferred into a chimney glass provided with sugar syrup $10 \%$ and tissue for laying eggs.

Original Egyptian local isolate of $S$. littoralis multiple nucleopolyhedrovirus (SpliMNPV) by Abul Nasr (1956) was used in all/separate experiments. The pathogenicity of SpliMNPV was evaluated on the second instar larvae of $S$. littoralis. Eight different virus concentrations $0.0,1 \times 10^{3}$, $5 \times 10^{3}, 1 \times 10^{4}, 5 \times 10^{4}, 1 \times 10^{5}, 5 \times 10^{5}, 1 \times 10^{6} \mathrm{BIPs} / \mathrm{ml}$ (polyhedral inclusion bodies/ml) were prepared from the stock concentration $\left(2.3 \times 10^{9} \mathrm{PIB} / \mathrm{ml}\right)$, and it was diluted in distilled water. The tested additives orange, marjoram and tea tree oils were provided from the local market (Haraz Group Co., LTD). Bioassays of the three essential oils were carried out using different concentrations and prepared in distilled water and Tween 80 .

\section{UV protection and prolonging viral activity}

The three tested oils, at $5 \%$ concentration, were added to SpliMNPV1 $\times 10^{8}$ (concentration of $\mathrm{LC}_{90-95}$ to neonate larvae). Larvae were exposed to ultraviolet as an artificial source of light (Utalix; 23 sun UV, Germany). This light was fixed in a hood with $50 \mathrm{~cm}$ distance away from glass Petri dishes containing virus with different additives. Treatments were at different exposure periods (zero time, 30, 60, 90, and $120 \mathrm{~min}$ ). Collected dishes were washed by distilled water and then collected virus was poured placed on the surface of a semi-artificial diet in 5 replicates. Each replicate was provided with 10 newly hatched larvae and observed till death or pupation (Shapiro et al. 2008).

\section{Bioassay experiments}

The impact of the tested additives for virus protection experiments was tested. The toxicities of either orange oil alone or in combination with SpliNPV on the eggs and larvae of $S$. littoralis were determined, while the tea tree and marjoram oils were eliminated for additional further experiments.

\section{Impact of orange oil odor on egg stage}

The direct effect of oil odor on eggs was also investigated. A small piece of cotton was fully saturated with different orange oil concentrations (1, 2, 3, 4, and 5\%). Each concentration was represented in 15 plastic cups, in three groups. Each group contains five replicates: in the first group, the cotton saturated with the concentration was removed after $24 \mathrm{~h}$, then 48 and $72 \mathrm{~h}$ in the second and third groups, respectively. These eggs were observed for hatching and viability on semi-artificial diet up to fifth day of larvae. Larvae were counted and the death percentage was calculated.

\section{Impact of orange oil on the larval stage}

The sensitivity of the neonate, second and fourth larval instars, to different oil concentrations (1, 2, 3, 4, and 5\%) were conducted. One milliliter of each concentration was provided to the surface of poured semi-artificial diet in plastic cups $(3 \times 3 \times 6 \mathrm{~cm})$, following the diet surface contamination technique. The process was repeated five times for each tested instar. Larvae were observed till pupation and mortality rates were recorded.

\section{Combination treatments}

The concentration-mortality responses of the either mixture (SpliMNPV and orange oil) or individual treatments were carried out following the diet surface contamination technique (Cisneros et al. 2002). The combination treatments (SpliMNPV and orange oil) were conducted using a mixture of SpliMNPV concentrations with the $\mathrm{LC}_{25}$ of orange oil and also vice versa, following the procedure of the methods mentioned above. The mortality responses of the larvae were recorded daily in each treatment. Evaluation of the combined treatment compared to the single ones was identified according to (Mansour et al. 1966) the following: Co-toxicity factor $(\%)=(\%$ Observed mortality $-\%$ Expected mortality $/ \%$ Expected mortality), where the factor $(-20$ to +20$)$ is additive, +20 or more is potentiation, and -20 or more is antagonism.

\section{Biological parameters}

The impact of orange oil concentrations on the biological parameters of treated S. littoralis second instar larvae was evaluated. Larval and pupal durations were recorded. The percentages of pupation, pupal 


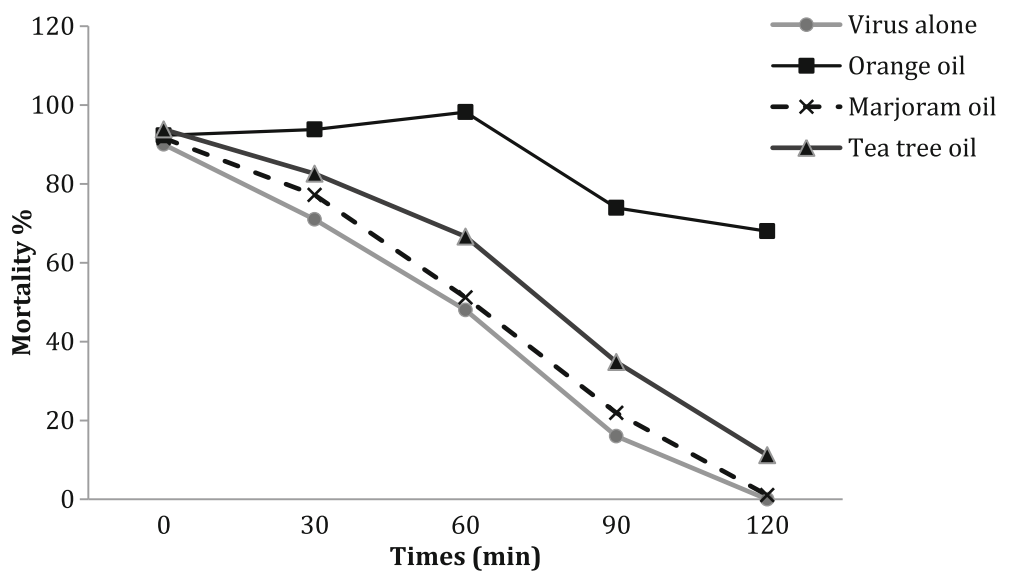

Fig. 1 Effect of UV irradiation on either SpliNPV or in combination with orange, marjoram, and tea tree oils

malformation, and adult emergence were observed. Moreover, the adult longevity was determined. Each treatment was replicated five times, and every replicates contained 50 individuals.

\section{Statistical analysis}

The percentages of original activity remaining (\% OAR) were carried out according to Muro and Paul (1985) and were calculated as the formula of Sun's model at each UV exposure time (Sun et al. 2004). The results were collected and analyzed according to Ignoffo and Batzer (1971) with the following formula: \% OAR $=100 \times$ e $(-r$ $\mathrm{xt}$ ); $95 \%$ confidence limits of $r$ as relative rate of inactivation $(h-1)$ were compared between LdMNPV $-45 / 0$ and $-27 / 0$. The half-life of each isolate was calculated from the following formula: $\tau 1 / 2=\ln (2) / r$, and its $95 \%$ confidence limit were compared to reveal significant differences. The mortality responses of several treatments in either applying SpliMNPV or plant oils were tested using the Probit analysis; slope and $\mathrm{LC}_{50}$ were calculated according to LDP line (http:// www.ehabsoft.com.). Statistical 12.0, Sigma Plot 12.5, and Graph Pad Prism 5 software were used. The data of biological studies were analyzed by analysis of variance (ANOVA) and the means were analyzed using Tukey's multiple range test $(P=0.01)$ (Steel and Torrie 1960).

\section{Results and discussion}

\section{Impact of tested oils on UV protection}

Inactivation of SpliMNPV was shown at 30-min exposure time either alone or combined with tea tree and marjoram oils, where the mortality percentages were significantly decreased as the UV exposure times increased. Orange oil was the highly effective in prolonging SpliMNPV activity Fig. 1. Meanwhile, the mortality percentages at 120-min UV exposure time were drastically lower (0.0 and 1.07) in SpliMNPV alone and
SpliMNPV + marjoram oil, respectively, than in SpliMNPV + tea tree oil and SpliMNPV + orange oil (11.2 and 68\%, respectively). The data of original activity remaining (\% OAR) in Table 1 demonstrated that the combination of SpliMNPV with orange oil was higher \% OAR (73.67\%) than in the combinations with tea tree oil, marjoram oil, and SpliMNPV alone (11.93, 1.16, and $0.0 \%$ OAR, respectively) at 120-min UV exposure time. The loss of the potency of the SpliMNPV either alone or with both tea tree and marjoram oils was associated with the theoretical of the direct effects of UV light on viral DNA (Ignoffo et al. 1989 and Douki et al. 1999) and/or on polyhedral protein surrounding the viral DNA (Ignoffo et al. 1977 and Eischeid and Linden 2011). The variations of SpliMNPV activation by tested antioxidant oils are in line with those investigated by Shapiro et al. (2009a) for using plant extracts against UV radiation to protect $S$. exigua nucleopolyhedrovirus (SeMNPV). They ranged those natural products from weak to excellent. Despite the water-derived material of green tea recommended as a highly effective protectant (El-Helaly et al. 2013), the tea tree oil in the present study was ineffective for viral protection. Furthermore, the marjoram oil had a weak effect as a protectant for viral inactivation; however, it was described as a highly

Table 1 (\%) OAR of the effect of orange, marjoram, and tea tree oils as protective additives to Spodoptera littoralis nucleopolyhedrovirus

\begin{tabular}{lllll}
\hline $\begin{array}{l}\text { Experimental } \\
\text { time/min }\end{array}$ & SpliNPV & \multicolumn{3}{l}{ SpliNPV +essential oils } \\
\cline { 3 - 5 } & & Orange & Marjoram & Tea tree \\
\hline Zero time & - & - & - & - \\
30 min & 79.33 & 100.00 & 84.34 & 87.96 \\
60 min & 53.33 & 96.64 & 55.96 & 64.52 \\
90 min & 18.01 & 80.07 & 23.95 & 37.06 \\
120 min & 0.00 & 73.67 & 1.16 & 11.93 \\
\hline
\end{tabular}


Table 2 Percentages of unhatched Spodoptera littoralis eggs in three exposure periods to different concentrations of orange odor

\begin{tabular}{lllllll}
\hline Experimental & \multicolumn{6}{l}{ Orange odor concentrations (\%) } \\
\cline { 2 - 7 } time/hours & 0.0 & 1.0 & 2.0 & 3.0 & 4.0 & 5.0 \\
\hline 24 & $3.0 \mathrm{a}$ & $4.23 \mathrm{~b}$ & $5.21 \mathrm{a}$ & $7.24 \mathrm{~b}$ & $8.25 \mathrm{~b}$ & $10.24 \mathrm{~b}$ \\
48 & $2.9 \mathrm{a}$ & $5.27 \mathrm{~b}$ & $8.24 \mathrm{~b}$ & $9.78 \mathrm{ab}$ & $9.77 \mathrm{~b}$ & $12.37 \mathrm{~b}$ \\
72 & $2.8 \mathrm{a}$ & $14.25 \mathrm{a}$ & $16.24 \mathrm{c}$ & $17.28 \mathrm{a}$ & $20.21 \mathrm{a}$ & $30.74 \mathrm{a}$ \\
$\mathrm{LSD}$ & 0.24 & 5.9 & 4.41 & 8.38 & 7.18 & 12.019 \\
$P$ & 0.0342 & 0.016 & 0.000 & 0.0072 & 0.0004 & 0.003 \\
\hline
\end{tabular}

effective antioxidant agent (Hossain et al. 2012), for which it could be suggested that the plant essential oils may have distinct characteristics as protectant agents against UV radiation. In contrast, obtained results revealed that orange oil had a high effect on virus tolerance against UV. This effect may be due to two high actions of orange oil: its antioxidant activity (Jayaprakasha et al. 2008) and toxicity properties (Tripathi et al. 2009). From the aforementioned results, it can be concluded that the orange oil was a distinct protective additive much more than both the tea tree and marjoram oils, which were negative additives.

\section{Ovicidal activity of orange oils}

Reverse relationships were noticed in egg hatching with both exposure periods and orange oil odor concentrations (Table 2). The highest percentage $(30.7 \%)$ of unhatched eggs was observed at the longest exposure time $(72 \mathrm{~h})$ and the highest concentration (5\%) of orange oil odor, while the lowest percentage $(4.23 \%)$ was provided in the case of $1 \%$ concentration and 24 -h exposure time. The obtained results indicated that the percentages of unhatched eggs of 72-h exposure periods were increased significantly than the 24 and $48 \mathrm{~h}$, while the percentages of $48 \mathrm{~h}$ were insignificantly increased than the 24-h exposure time at all concentration treatments. The low ovicidal activity of orange oil was contradicted to that of Phasomkusolsil and Soonwera (2012) who found high mortality rates $(56.8,53.6$, and $76.3 \%)$ in the egg of the mosquitos species, Aedes aegypti, Anopheles dirus, and Culex quinquefasciatus, respectively, after exposure to $5 \%$ orange (Citrus sinensis) oil concentration at 3-h exposure time. The ovicidal activity of other plant oils has been attempted on various insect pests; for instance, $\mathrm{Al}$ lium sativum failed the S. litura eggs to hatch (Gurusubramanian and Krishna, 1996) and the cinnamon, clove, and cardamom oils, which achieved 100\% inhibition of Tribalism castaneum eggs at $5.769 \mathrm{mg} / \mathrm{l}$ air concentration and 24-h exposure period (Mondal and Khalequzzaman 2009). Moreover, T. confusum and Ephestia kuehniella eggs were completely unhatched by cumin and anise oils treatments (Iskkber et al. 2009). The ovicidal action of oils may be due to one or more of the following mechanisms: oxygen depletion for embryonic respiration, biochemical processes, hormonal suppressions, and/or blocking of the micropyle region of the egg chorion (Tunc et al. 2000).

\section{Larvicidal activity of orange oils}

The sensitivity of the neonat and the second and fourth larval instars against orange oil was obviously different, as the $\mathrm{LC}_{50}$ (9314.1) of the fourth instar larvae was drastically higher than those calculated (5.4 and 1.84) of the second and neonate larval instars, respectively (Fig. 2). The obtained results revealed that the fourth instar larvae were tolerant to orange oil, while the neonate ones were more sensitive than the second instar larvae in response to orange oil concentrations. The toxicity effect

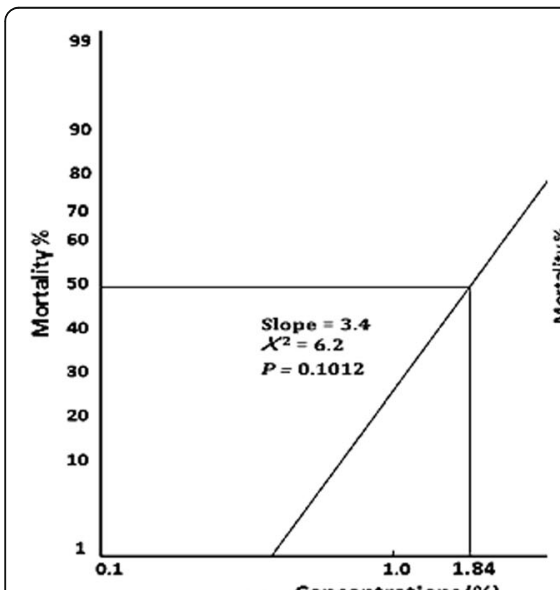

(a)

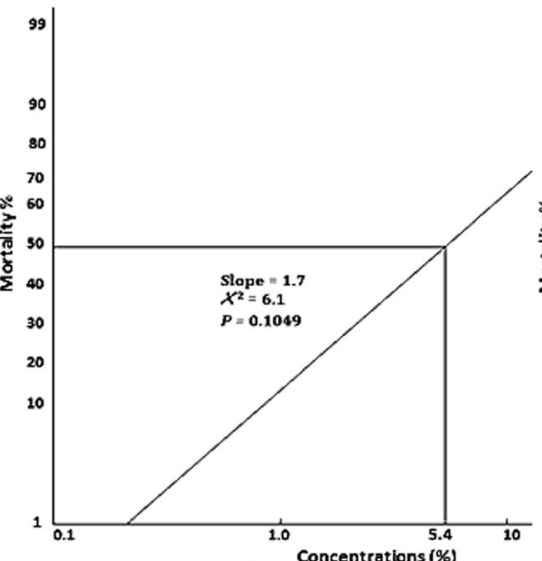

(b)

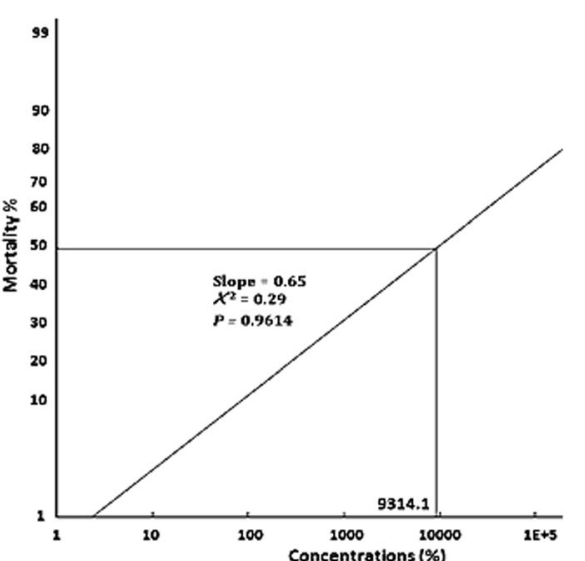

(C)

Fig. 2 Larvicidal activity of orange oil on different instar larvae of Spodoptera littoralis. (a) neonate instar, (b) secound instar, (c) fourth instar 


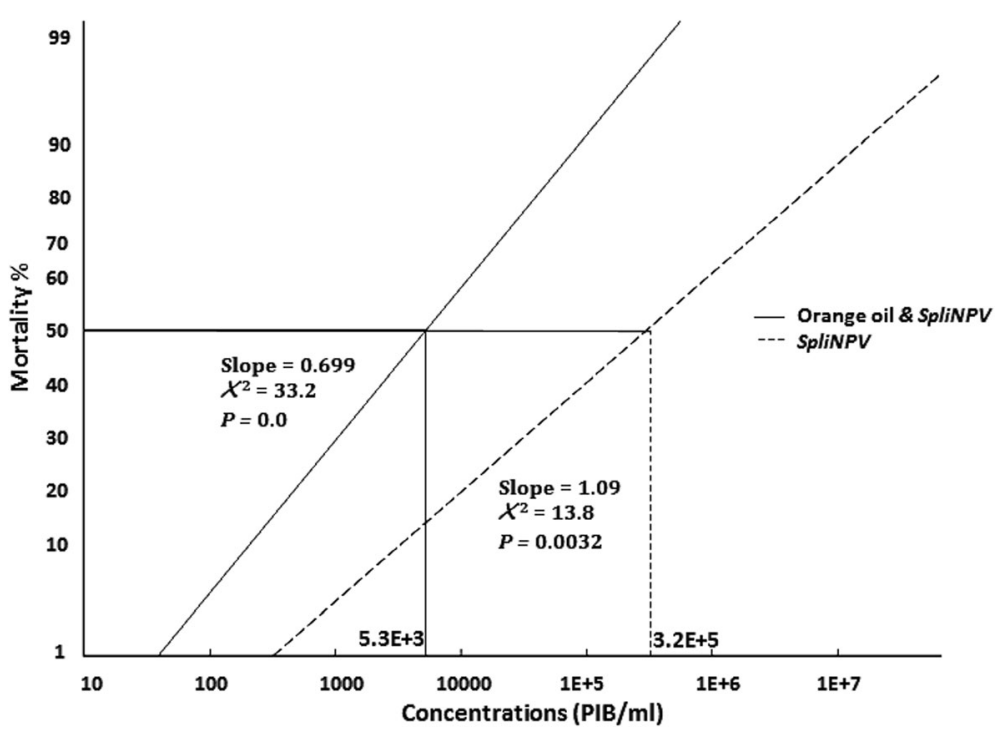

Fig. 3 Effect of orange oil on the SpliNPV pathogenicity against Spodoptera littoralis

of orange oil upon insect pest may be due to the high percentage of limonene component (92-96\%) in its constituents. Limonene component was reported as a toxic agent against some insect pests and usually used as insecticide to control ectoparasites of pet animals (Raina et al. 2007). The findings of the present study coincide with those recorded on mosquitos concerning larvicidal activity of orange oil (Murugan et al. 2012). Similarly, the orange oil was reported as a toxic agent on stored product insect pests (Don-Pedro 1996) Ceratitis capitata (Wied.) (Papachristos et al. 2009) and Musca domestica (Linn.) (Tarelli et al. 2009).

\section{Combination treatment of orange oil and SpliMNPV}

The mortality response of SpliMNPV was increased drastically by adding the $\mathrm{LC}_{25}(1 \%)$ of orange oil, where the $\mathrm{LC}_{50}$ of the mixture was reduced to $5.3 \times 10^{3} \mathrm{PIB} / \mathrm{ml}$ concentration than $3.2 \times 10^{5} \mathrm{PIB} / \mathrm{ml}$ concentration of the virus alone (Fig. 3). The co-toxicity factor, calculated in this study, revealed that the mixture of $1.0 \%$ orange oil and SpliMNPV $10^{3}, 10^{4}, 10^{5}, 10^{6} \mathrm{PIB} / \mathrm{ml}$ concentrations were $75,75.8,45$, and $38 \%$, respectively. These percentages indicated a potentiation effect. On the other hand, when adding the sub-lethal concentration of SpliMNPV $\left(1 \times 10^{3} \mathrm{PIB} / \mathrm{ml}\right)$ to the orange oils, the

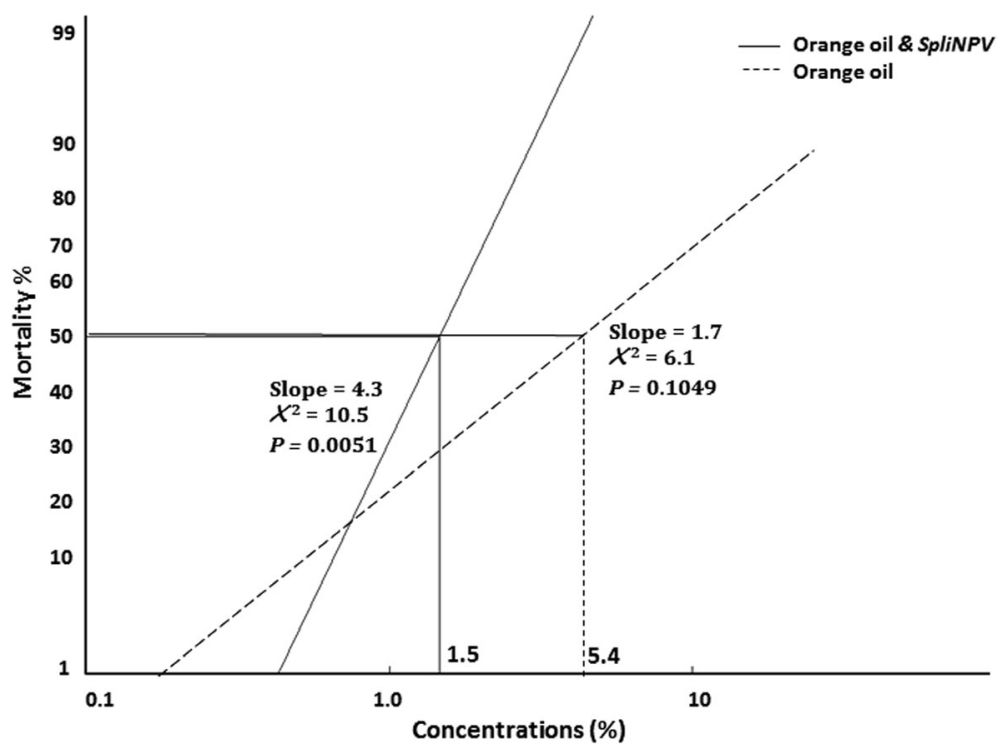

Fig. 4 Effect of SpliNPV on orange oil toxicity against Spodoptera littoralis 
Table 3 Effect of orange oil concentrations on certain reproductive biology of Spodoptera littoralis treated as second instar larvae

\begin{tabular}{lllllll}
\hline Concentration (\%) & (Avg.) Larval duration & (\%) Pupation & (\%) Malform-ation & (Avg.) Pupal duration & (\%) Adult emergence & (Avg.) adult longevity \\
\hline 0.0 & $20.4 \mathrm{~d}$ & $85.0 \mathrm{a}$ & $1.0 \mathrm{c}$ & $14.6 \mathrm{a}$ & $85.8 \mathrm{a}$ & $10.2 \mathrm{ab}$ \\
1.0 & $27.4 \mathrm{~b}$ & $84.1 \mathrm{a}$ & $1.2 \mathrm{c}$ & $15.2 \mathrm{a}$ & $86.2 \mathrm{a}$ & $9.8 \mathrm{~b}$ \\
2.0 & $29.3 \mathrm{bc}$ & $84.0 \mathrm{a}$ & $1.4 \mathrm{c}$ & $14.8 \mathrm{a}$ & $85.6 \mathrm{a}$ & $9.8 \mathrm{~b}$ \\
3.0 & $26.9 \mathrm{bc}$ & $80.2 \mathrm{~b}$ & $1.8 \mathrm{c}$ & $15.0 \mathrm{a}$ & $81.0 \mathrm{~b}$ & $10.3 \mathrm{ab}$ \\
4.0 & $28.0 \mathrm{c}$ & $76.6 \mathrm{c}$ & $6.8 \mathrm{~b}$ & $14.4 \mathrm{a}$ & $80.8 \mathrm{~b}$ & $11.2 \mathrm{a}$ \\
5.0 & $34.0 \mathrm{a}$ & $70.2 \mathrm{~d}$ & $9.4 \mathrm{a}$ & $16.2 \mathrm{a}$ & $75.4 \mathrm{c}$ & $11.4 \mathrm{a}$ \\
LSD & 1.99 & 2.52 & 1.48 & 1.48 & 2.24 & 0.968 \\
$P$ & 0.00 & 0.000 & 0.000 & 0.0345 & 0.000 & 0.0001 \\
\hline
\end{tabular}

mortality percentages were increased by low $\mathrm{LC}_{50}(1.5 \%)$ than the $\mathrm{LC}_{50}(5.4 \%)$ of orange oil alone (Fig. 4). The cotoxicity factor of this combination treatment indicated a potentiation effect. The calculated co-toxicity factors were 53,62 , and $72 \%$ at the orange oil concentrations of 1,2 , and $3 \%$, respectively with the mixture of $1 \times 10^{3}$ $\mathrm{PIB} / \mathrm{ml}$ SpliMNPV concentrations. The obtained results of orange oil as a synergistic agent of NPV infectivity may be referred to the direct effect of orange oil on the cell membrane permeability, and/or on the hormonal insects and the immunity system (Tripathi et al. 2009). The positive relationship of the SpliMNPV pathogenicity and orange oil is in line with several investigations of increasing the efficacy of NPV infectivity in combinations with different adjunct substances, such as Chlorantrani liprole with Helicoverpa armigera NPV (HaSNPV) (Wakil et al. 2012), Azadirachtin with SpliMNPV (Shaurub et al. 2014), and Spinosad with $A g$ MNPV (Jackson et al. 2014).

\section{Effect of orange oil on reproductive biology}

It is obvious that the larval stage was the most sensitive one than the other stages (pupae and adults), where it became too long as a latent effect of orange oil treatments (Table 3). Meanwhile, the averages of larval duration were significantly longer $(27.4,29.3,26.9,28.0$, and 34.00 days) in $1,2,3,4$, and $5 \%$ orange oil concentrations, respectively, than in the control treatment $(20.4$ days). These results demonstrated that the larvae were very sensitive to the orange oil treatments. This prolongation of larval period may help for increasing the efficacy of Baculovirus activity. Nonetheless, the malformations of pupae resulted from the treated larvae were significantly higher in 4 and $5 \%$ concentrations than in $0,1,2$, and $3 \%$ concentrations. As depicted in the same table, there were insignificant differences in the pupal durations among the concentration treatments. Moreover, the data revealed that both pupal and adult emergence percentages were significantly increased at 3, 4, and $5 \%$ concentrations than at 0,1 , and $2 \%$ concentrations. The aforementioned results revealed that the orange oil had a negative impact on some biological properties at all tested concentrations. This influence on reproductive biology of treated larvae may be due to the direct action of orange oil on the physiological balance and hormonal changes of the insect. These results are in accordance with Bakkali et al. (2008) and Sharifi-Rad et al. (2017) who reported negative impacts of essential plant oils on insect biological parameters which suppress the population of target pest.

\section{Conclusions}

The activity of the entomopathogenic agent SpliMNPV by using plant essential oil toxicity actions was studied. Orange oil was excellent for virus protection against UV irradiation, while the tea tree oil was weak and the marjoram oil has negative effect. The orange oil was highly toxic against $S$. littoralis larvae either alone or in combination with SpliMNPV. Using the combination of Baculovirus and orange oils may help in developing the lepidopteran pest management strategy.

\section{Acknowledgements}

The authors wish to express their gratitude to Prof. Dr. Salah Alnagar from the Faculty of Agriculture, Cairo University, and Prof. Dr. Awatef Fadel from the Atomic Energy Authority for revising the manuscript. The authors also wish to thank Prof. Dr. Adel Hatem and Dr. Gamal Hassan from the Plant Protection Institute Research, Ministry of Agriculture, Giza, Egypt, for the helpful discussion and technical support of the manuscript.

\section{Authors' contributions}

Authors HE and AE carried out the bioassay study. AE conducted the isolation and propagation of the Baculovirus and prepared the virus suspension. AE and WS carried out the biological studies and statistical analysis. $\mathrm{HE}, \mathrm{AE}$, and WS contributed in the experimental design and writing of the manuscript. All authors read and approved the final manuscript.

Funding

Not applicable.

Availability of data and materials

The authors declare that they have no objection to the availability of data and materials.

Ethics approval and consent to participate

Not applicable.

Consent for publication

Not applicable. 


\section{Competing interests}

The authors declare that they have no competing interests.

\section{Author details}

'Biological Application Department, Nuclear Research Center, Atomic Energy Authority Cairo, Cairo, Egypt. ${ }^{2}$ Plant Protection Department, Faculty of Agriculture, Fayoum University, Fayoum, Egypt. ${ }^{3}$ Department of Economic Entomology and Pesticides, Faculty of Agriculture Cairo University, Giza, Egypt.

Received: 23 October 2019 Accepted: 27 December 2019 Published online: 03 February 2020

\section{References}

Abul Nasr S (1956) Polyhedrosis virus disease on cotton leaf worm Spodoptera littoralis. Bull Entom Soc Egypt, Econ Ser 40:321-332

Bakkali F, Averbeck S, Averbeck D, Idaomar M (2008) Biological effects of essential oils-a review. Food Chem Toxicol 46:446-475

Cisneros J, Peterz JA, Penagos DI, Ruiz D, Goulson P, Caballero P, Williams T (2002) Formulation of baculovirus with boric acid for control of Spodoptera frugiperda (Lepidoptera: Noctuidae). Biolog Contr 23:87-95

Cory JS, Myers JH (2003) The ecology and evolution of insect baculoviruses. Ann review of Ecology Evolut System 34:239-272

Don-Pedro KN, (1996) Fumigant Toxicity of Citruspeel Oils against Adult and Immature Stages of Storage Insect Pests. Pesticide Science 47(3):213-223.

Douki T, Perdiz D, Grof P, Kuluncsics Z, Moustacchi E, Cadet J, Sage E (1999) Oxidation of guanine in cellular DNA by solar UV radiation: biological role. J Photoch Photobiolog 70:184-190

Eischeid AC, Linden KG (2011) Molecular indications of protein damage in adenoviruses after UV disinfection. Appl Environ Microbiol 77:1145-1147

El-Helaly A, Khattab M, El-Salamouny S, El-Sheikh M, Elnagar S (2013) Promising additives to protect the activity of Baculovirus biocontrol agent under fieldsunlight conditions in Egypt. J Life Sci 7(5):495-500

Gurusubramanian G, Krishna SS (1996) The effects of exposing eggs of four cotton insects pests to volatiles of Allium sativum (Liliaceae). Bull Entomol Res 86:29-31

Hossain MB, Brunton NP, Patras A, Tiwari B, O'donnell CP, Martin-Diana AB, BarryRyan C (2012) Optimization of ultrasound assisted extraction of antioxidant compounds from marjoram (Origanum majorana $\mathrm{L}$.) using response surface methodology. Ultrason Sonochem 19(3):582-590

Ignoffo CM, Batzer OF (1971) Microencapsulation and ultraviolet protectants to increase sunlight stability of an insect virus. J Econ Entomol 64:850-853

Ignoffo CM, Hostetter DL, Sikorowski PP, Sutter G, Brooks WM (1977) Inactivation of representative species of entomopathogenic viruses, a bacterium, fungus, and protozoan by an ultraviolet light source. J Environ Entomol 6:411-415

Ignoffo CM, Rice WC, McIntosh AH (1989) Inactivation of nonoccluded and occluded Baculoviruses and Baculovirus-DNA exposed to simulated sunlight. J Environmental Entomology 18(1):177-183

Isıkber AA, Ozder N, Sağlam O (2009) Susceptibility of eggs of Tribolium confusum, Ephestia kuehniella and Plodia interpunctella to four essential oil vapors. Phytoparasitica 37:231-239

Jackson DM, Shapiro M, Shepard BM (2014) Effects of Spinosad and Neem on the efficacy of a Nucleopolyhedrovirus on Pickleworm Larvae 1. J Agric Urban Entomol 30(1):28-38

Jayaprakasha GK, Girennavar B, Patil BS (2008) Antioxidant capacity of pummelo and navel oranges: extraction efficiency of solvents in sequence. LWT-Food Sci Technol 41:376-384

Jones KA, Moawad G, McKinley DJ, Grzywacz D (1993) The effect of natural sunlight on Spodoptera littoralis nuclear polyhedrosis virus. J Biocontrol Science Tech 3:189-194

Liao M, Xiao JJ, Zhou LJ, Liu Y, Wu XW, Hua RM, Cao HQ (2016) Insecticidal activity of Melaleuca alternifolia essential oil and RNA-Seq analysis of Sitophilus zeamais transcriptome in response to oil fumigation. PLoS One 11(12):e0167748

Mansour NA, Eldefrawi ME, Tappozada A, Zied M (1966) Toxicological studies on the Egyptian cotton leaf worm Prodenia litura F. VII Potentiation and antagonism of órgano-phosphorus and carbamates. J Econom Entomol 59:307-311

Miguel MG (2010) Antioxidant and anti-inflammatory activities of essential oils: a short review. Molecules 15(12):9252-9287

Mondal M, Khalequzzaman M (2009) Ovicidal activity of essential oils against red flour beetle, Tribolium castaneum (Coleoptera: Tenebrionidae). J Bio-Scie 17:57-62

Muro EM, Paul JI (1985) Laboratory evaluation of new ultraviolet absorbers for protection of Douglas-fir tussock moth (Lepidoptera: Lymantriidae) Baculovirus. J Econ Entomol 78:951-957
Murugan K, Kumar PM, Kovendan K, Amerasan D, Subrmaniam J, Hwang JS (2012) Larvicidal, pupicidal, repellent and adulticidal activity of Citrus sinensis orange peel extract against Anopheles stephensi, Aedes aegypti and Culex quinquefasciatus (Diptera: Culicidae). Parasitolo Rese 111(4):1757-1769

Padin S, Ringuelet JA, Bello D, Cerimele EL, Re MS, Henning CP (2000) Toxicology and repellent activity of essential oils on Sitophilus oryzae L. and Tribolium castaneum Herbst. J Herbs Spic Med Plants 7(4):67-73

Papachristos DP, Kimbaris AC, Papadopoulos NT, Polissiou MG (2009) Toxicity of citrus essential oils against Ceratitis capitata (Diptera: Tephritidae) larvae. Ann Appli Biol 155(3):381-389

Phasomkusolsil S, Soonwera M (2012) The effects of herbal essential oils on the oviposition deterrent and ovicidal activities of Aedes aegypti (Linn.), Anopheles dirus (Peyton and Harrison) and Culex quinquefasciatus (Say). Trop Biomed 29(1):138-150

Raina AK, Bland J, Dollittle M, Lax A, Boopathy R, Lolkins M (2007) Effect of orange oil extract on the formosan subterranean termite (Isoptera: Rhinotermitidae). J Econ Entomol 100:880-885

Regnault-Roger C, Vincent C, Arnason JT (2012) Essential oils in insect control: low-risk products in a high-stakes world. Annu Rev Entomol 57:405-424

Sayed WAA, El-Helaly AMA (2018) Effect of gamma irradiation on the susceptibility of the cotton leaf worm, Spodoptera littoralis (Boisd.) (Lepidoptera: Noctuidae) to the infection with nucleopolyhedrosis virus. Egyptian J Biol Pest Control 28(1):73

Shapiro M, El Salamouny S, Shepard BM (2009a) Plant extracts as ultraviolet radiation protectants for the beet armyworm (Lepidoptera: Noctuidae) nucleopolyhedrovirus: screening of extracts. J Agr Urba Entom 26(2):47-62

Shapiro M, El Salamouny S, Shepard BM, Jackson DM (2009b) Plant phenolics as radiation protectants for the beet armyworm (Lepidoptera: Noctuidae) nucleopolyhedrovirus. J Agric Urba Entomol 26(1):1-11

Shapiro M, El-Salamouny S, Shepard BM (2008) Green tea extracts as ultraviolet protectants for the beet armyworm, Spodoptera exigua nucleopolyhedrovirus. Biocon Sci Tech 18(6):591-603

Shapiro M, Robertson JL, Webb RE (1994) Effect of neem seed extract upon the gypsy moth (Lepidoptera: Lymantriidae) and its nuclear polyhedrosis virus. J Econ Entom 87(2):356-360

Sharifi-Rad J, Sureda A, Tenore GC, Daglia M, Sharifi-Rad M, Valussi M, Sharifi-Rad $R$ (2017) Biological activities of essential oils: from plant chemoecology to traditional healing systems. Molecules 22(1):70

Shaurub ESH, El-meguid A, Abd El-aziz NM (2014) Effect of individual and combined treatment with Azadirachtin and Spodoptera littoralis multicapsid nucleopolyhedrovirus (SpliMNPV, Baculoviridae) on the Egyptian cotton leaf worm Spodoptera littoralis (Boisduval) (Lepidoptera: Noctuidae). Ecological Balkanica 6(2):93-100

Shorey H, Hale RL (1965) Mass rearing of the larvae of nine noctuid species on a simple artificial medium. J Econo Entom 58:522-524

Steel RGD, Torrie JH (1960) Principles and procedures of statistics. McGraw-Hill Book Company, New York, p 481

Sun XL, Wang HL, Sun XC, Chen XW, Peng CM, Pan DM, Jehle JA, Van der Werf W, Vlak JM, Hu ZH (2004) Biological activity and field efficacy of a genetically modified Helicoverpa armigera SNPV expressing an insect-selective toxin from a chimeric promoter. Biol Control 29:124-137

Tarelli G, Zerba EN, Alzogaray RA (2009) Toxicity to vapor exposure and topical application of essential oils and monoterpenes on Musca domestica (Diptera: Muscidae). J Econom Entomo 102(3):1383-1388

Trang TTK, Chaudhari S (2002) Bioassay of nuclear polyhedrosis virus (NPV) and in combination with insecticide on Spodoptera litura (Fab). Omonrice 10:45-53

Tripathi AK, Upadhyay S, Bhuiyan M, Bhattacharya PR (2009) A review on prospects of essential oils as biopesticide in insect-pest management. J Pharma Phytoth 1(5):52-63

Tunc I, Berger BM, Erler F, Dağlı F (2000) Ovicidal activity of essential oils from five plants against two stored-product insects. J Stored Pro Res 36(2):161-168

Wakil W, Ghazanfar MU, Nasir F (2012) Insecticidal efficacy of Azadirachta indica, nucleopolyhedrovirus and chlorantraniliprole singly or combined against field populations of Helicoverpa armigera Hübner (Lepidoptera: Noctuidae). Chilean J Agricu Res 72:53-61

Yoon JH, Lee CS, O'Connor TR, Yasui A, Pfeifer GP (2000) The DNA damage spectrum produced by simulated sunlight. J Molec Biol 299:681-693

\section{Publisher's Note}

Springer Nature remains neutral with regard to jurisdictional claims in published maps and institutional affiliations. 